\title{
PENGUJIAN SISTEM INFORMASI PELAYANAN PUBLIK KEPOLISIAN RESOR KABUPATEN KUDUS
}

\author{
Rina Fiati ${ }^{1}$, Anastasya Latubessy ${ }^{2}$, Ahmad Jazuli ${ }^{3}$ \\ ${ }^{123}$ Universitas Muria Kudus \\ Email: ${ }^{1}$ rina.fiati@umk.ac.id, ${ }^{2}$ anastasya.latubessy@umk.ac.id, ${ }^{3}$ ahmad.jazuli@umk.ac.id
}

(Naskah masuk: 27 Mei 2021, diterima untuk diterbitkan: 24 Juni 2021)

\begin{abstract}
Abstrak
Kegiatan pelayanan publik merupakan proses aktivitas untuk memenuhi kebutuhan pelayanan umum yang sesuai dengan aturan yang berlaku bagi setiap warga negara terhadp produk maupun jasa, dan/atau pelayanan yang bersifat administratif yang menjadi tugas yang harus dilakukan oleh penyelenggara pelayanan publik. Kepolisian merupakan salah satu instansi yang diberi amanah dalam melakukan pelayanan terhadap publik. Proses layanan umum yang baik membutuhkan sarana yang tepat. Diera perkembangan teknologi saat ini, kepolisian ingin mengadopsi teknologi digital untuk membantu proses pelayanan publik. Salah satu teknologi yang dapat membantu adalah Sistem Informasi. Oleh sebab itu, dalam penelitian kerja sama antara Program Studi Teknik Informatika denga Kepolisian Resor Kudus yang tertuang dalam perjanjian kerjasama, maka dibuatkan sebuah Sistem Informasi terpadu yang dapat digunaka untuk proses pelayanan informasi. Dengan harapan proses pelayanan publik di kepolisian resor kudus dapat dilaksakan dengan lebih baik.
\end{abstract}

Kata kunci: sistem, informasi, kepolisian

\section{PUBLIC SERVICE INFORMATION SYSTEM OF KUDUS DISTRICT POLICE RESORTS}

\begin{abstract}
Public service activities are a process of activities to meet the needs of public services in accordance with the rules that apply to every citizen of products and services, and/or services of an administrative nature which are tasks that must be carried out by public service providers. The police are one of the institutions that are given the mandate to provide services to the public. A good public service process requires the right tools. In the current era of technological developments, the police want to adopt digital technology to assist the public service process. One technology that can help is Information Systems. Therefore, in the collaborative research between the Informatics Engineering Study Program and the Kudus Resort Police as stated in the cooperation agreement, an integrated information system is made that can be used for the information service process. It is hoped that the public service process at the Kudus Resort Police can be carried out better.
\end{abstract}

Keywords: system, information, police

\section{PENDAHULUAN}

Perkembangan teknologi di zaman era digital sekarang ini, menuntut pelayanan publik dengan memanfaatkan teknologi yang ada. Informasi yang dibutuhkan masyarakat dapat cepat tersampaikan melalui media-media teknologi. Salah satu media teknologi yang harus dimiliki oleh setiap instansi dalam meningkatkan pelayanan publik adalah WEBSITE sebagai Sistem Informasi Terpadu. Hampir seluruh instansi telah memiliki website masing-masing. Website adalah sebuah kumpulan dari halaman web yang saling berhubungan dan dapat diakses melalui halaman depan (homepage) menggunakan sebuah browser dan juga jaringan internet. Melalui penggunaan website akses informasi akan lebih mudah diperoleh masyarakat zaman sekarang yang notabene sudah melek teknologi.

Hal tersebut menuntut Kepolisian Resor Kudus juga melakukan perubahan-perubahan kearah digitalisasi. Langkah awal yang baik adalah dengan pembuatan website kepolisian resor kudus yang berisi informasi-informasi layanan publik.

Oleh sebab itu, pembuatan website kepolisian resor Kudus berisikan menu-menu sebagai berikut: home, profil, info layanan,bagian, satuan fungsi, 
seksi, polsek, spkt, aduan, dan survey kepuasan masyarakat. Semua menu yang tampil pada halaman website adalah berdasarkan hasil diskusi dengan humas kepolisian resor Kabupaten Kudus. Sehingga website yang dihasilkan sudah sesuai dengan permintaan pengguna sistem.

\section{KERANGKA TEORI}

Beberapa penelitian serupa yang pernah melakukan perancangan dan implementasi sistem informasi terkait pelayanan publik antara lain: Melakukan pembuatan sistem informasi publik yang diperuntukan untuk desa durian kecamatan padang cermin. Teknologi yang digunakan adalah teknologi web. (Melinda M, dkk.,2017).

Adapun pengembangan sistem informasi juga terus dilakukan oleh beberapa instansi pemerintah, seperti di Kantor Kecamatan yang melakukan pengembangan sistem informasi untuk menunjang proses pelayanan surat keterangan di Desa Legundi Kecamatan Karangjati Kabupaten Ngawi (Winarna, T.R., dkk.,2018).

Kantor Kelurahan juga menerapkan sistem informasi melalui pembuatan sistem informasi yang diperuntukan dalam proses pelayanan masyarakat pada kantor kelurahan Guntung Paikat Banjar Baru (Soegiarto, dkk.,2018).

Instansi pendidikan seperti sekolah dasarpun tidak mau ketinggalan, dengan pembuatan sistem informasi dalam proses evaluasi pelayanan publik, seperti pada penelitian yang melakukan pembuatan SIEVA(Sistem Informasi Evaluasi Pelayanan Publik) yang diterapkan di Sekolah Dasar Negeri pada Kementrian pendayagunaan aparatur nergara dan reformasi birokrasi (Betayunanda,R., dkk.,2015).

Terkait pelayanan publik, beberapa penelitian yang membahas hal tersebut diantaranya, pembuatan Sistem Informasi guna menunjang Pelayanan Publik menggunakan teknologi Web Pada Dinas Pekerjaan Umum Kabupaten Kampar (Ibrahim, W.H., dan Maita, I., 2017)

\section{METODE}

Adapun jenis penelitian yang dilakukan saat ini termasuk dalam penelitian deskriptif. Penelitian ini dapat dikategorikan dalam metode penelitian kualitatif . Metode yang digunakan adalah metode survei dengan menggambarkan, menjelaskan dan menginterpretasikan suatu kejadian yang terjadi pada suatu objek dan data bersifat kualitatif, yaitu data yang digambarkan dengan kata atau kalimat menurut kategori untuk memperoleh suatu kesimpulan.

Data primer yang digunakan adalah data yang diperoleh secara langsung dari mitra (Humas Kepolisian Resor Kudus), sementara data Sekunder yaitu, data yang diperoleh dari literatur-literatur yang ada. Dalam penelitian ini, kegiatan pengumpulan data dilakukan melalui Library Research, dimana pengumpulan data dilakukan dengan mempelajari pustaka tertulis berupa buku, browsing melalui internet terhadap masalah yang berkaitan.

Penelitian ini juga menggunakan metode wawancara, dimana proses ini dilakukan untuk pengumpulan data dengan menggunakan metode tanya jawab. Wawancara dilakukan untuk mendapatkan informasi yang sesuai berdasarkan fakta yang ada di masyarakat. Dari hasil wawancara akan diperoleh kebutuhan sistem yang akan digunakan oleh Humas Resor Kudus. Peneliti melakukan tanya jawab secara langsung dengan pihak-pihak yang berkaitan untuk memperoleh inforasi yang sesuai sehingga dapat digunakan utuk menghasilkan perancangan sistem informasi yang sesuai dengan kebutuhan Polres Kudus.

Selanjutnya dilakukan dokumentasi. Proses dokumentasi dilakukan untuk identifikasi sumber data, memperoleh informasi dari peristiwa terkait atau berupa variabel, notulen, informasi dari masyarakat dan sebagainya. Hal tersebut mengilustrasikan tempat penelitian secara umum sepanjang penelitian dilakukan untuk merekam situasi dan hal-hal yang terjadi selama penelitian dilakukan. Hal tersebut adalah salah satu kegiatan pengumpulan informasi mengenai dokumendokumen yang digunakan dalam suatu sistem. Tujuan dari analisis dokumen dilakukan adalah untuk identifikasi dokumen apa saja yang terlibat dan mengalir dalam suatu sistem yang berjalan.

Pengamatan (Observation) juga dilakukan. Peneliti melakukan pengamatan langsung Sistem kerja dari humas Resor Kudus dalam menanggapi keluhan informasi di masyarakat. Tahapan ini meliputi prosedur yang dilakukan peneliti dalam melakukan penelitian, disajikan secara lengkap dan rinci. Karena data yang lengkap dan jelas sangat akan sangat berguna dalam teknis analisis.

\section{HASIL DAN PEMBAHASAN}

Hasil penelitian ini menghasilkan sebuat website resmi kepolisian resor Kudus yang dapat diakses pada halaman https://polreskudus.com/. Gambar 1 menunjukkan tampilan awal website Polres Kudus. 


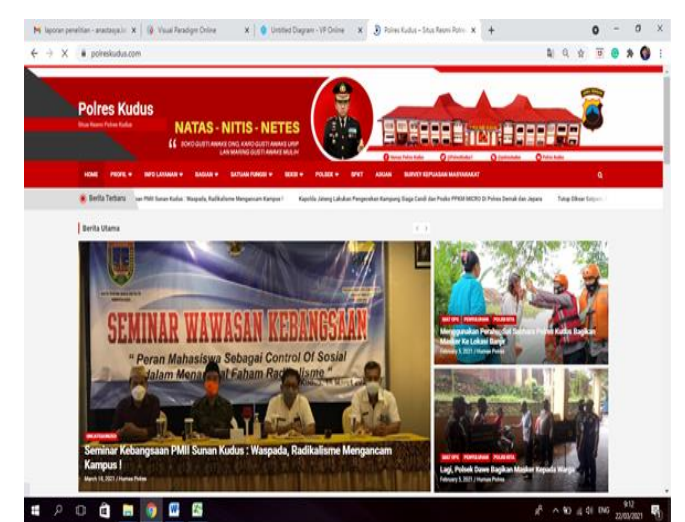

Gambar 1. Tampilan Awal Website Polres Kudus

Selanjutnya dilakukan pengujian Blackbox yang dilakukan untuk mengecek fungsionalitas sistem yang ada. Apakah website sudah berjalan dengan baik dan sesuai dengan fungsinya. Pengujian meliputi tujuh proses utama yaitu, proses login; proses input menu; proses input sub menu; proses lihat data input; proses update data menu; proses update data sub menu; proses hapus data.

Hasil pengujian menunjukkan bahwa fungsionalitas sistem yang ada pada website Polres Kudus sudah sudah sesuai dengan fungsionalitasnya. Tabel 1 juga menunjukkan bahwa hasil pengujian sudah kebutuhan sistem.

Tabel 1. Hasil Pengujian Blackbox Website Polres

\begin{tabular}{|c|c|c|c|}
\hline \multicolumn{4}{|c|}{ Kudus } \\
\hline No. & Proses & $\begin{array}{c}\text { Skenario } \\
\text { Pengujian }\end{array}$ & $\begin{array}{c}\text { Hasil } \\
\text { Pengujian }\end{array}$ \\
\hline \multirow[t]{13}{*}{1.} & Proses & Username dan & Login \\
\hline & Login & Password kosong & Gagal \\
\hline & & Username & Login \\
\hline & & kosong, & Gagal \\
\hline & & password benar & \\
\hline & & Username benar; & Login \\
\hline & & password kosong & Gagal \\
\hline & & Username & Login \\
\hline & & $\begin{array}{l}\text { benar;password } \\
\text { salah }\end{array}$ & Gagal \\
\hline & & Username & Login \\
\hline & & $\begin{array}{l}\text { salah;password } \\
\text { benar }\end{array}$ & Gagal \\
\hline & & Username & Login \\
\hline & & $\begin{array}{l}\text { benar;password } \\
\text { benar }\end{array}$ & Berhasil \\
\hline \multirow[t]{5}{*}{2.} & Proses & Isi tidak sesuai & Input \\
\hline & Input & format input & Gagal \\
\hline & Menu & menu & \\
\hline & & Isi sesuai format & Input \\
\hline & & input menu & Berhasil \\
\hline \multirow[t]{5}{*}{3.} & Proses & Isi tidak sesuai & Input \\
\hline & Input & format input sub & Gagal \\
\hline & Sub & menu & \\
\hline & Menu & & \\
\hline & & Isi sesuai format & $\begin{array}{l}\text { Input } \\
\text { Berhasil }\end{array}$ \\
\hline
\end{tabular}

\begin{tabular}{|c|c|c|c|}
\hline \multirow[t]{3}{*}{4.} & Lihat & Lihat informasi & Data \\
\hline & Data & yang diinput & Berhasil \\
\hline & Input & admin & Tampil \\
\hline \multirow[t]{4}{*}{5.} & Proses & Merubah data & Update \\
\hline & Update & menu yang telah & Berhasil \\
\hline & Data & ada & \\
\hline & Menu & & \\
\hline \multirow[t]{3}{*}{6.} & Proses & Merubah data & Update \\
\hline & Update & sub menu yang & Berhasil \\
\hline & $\begin{array}{l}\text { Data Sub } \\
\text { menu }\end{array}$ & telah ada & \\
\hline \multirow[t]{3}{*}{7.} & Proses & Menghapus & Hapus \\
\hline & Hapus & informasi yang & Data \\
\hline & data & ada & Berhasil \\
\hline
\end{tabular}

Pengujian juga dilakukan terhadap user enggunakan User Acceptance Testing. Pengujian beta yang dilakukan kepada 10 responden terhadap fungsional, antarmuka, dan kemanfaatan aplikasi dengan menggunakan kuesioner sebagai alat bantu ukur yang terdiri dari 14 pernyataan untuk persetujuan dari beberapa responden. Ke-14 Pernyataan yang ditujukkan untuk responden dapat dilihat pada Tabel 2.

Tabel 2. Daftar Pernyataan Pengujian Beta

\begin{tabular}{|c|c|}
\hline No & Pernyataan \\
\hline 1 & Kemudahan pengoperasian aplikasi \\
\hline 2 & $\begin{array}{l}\text { Kenyamanan menggunakan aplikasi secara } \\
\text { keseluruhan }\end{array}$ \\
\hline 3 & $\begin{array}{l}\text { Kesesuaian aplikasi dalam meningkatkan } \\
\text { efektifitas proses akses informasi }\end{array}$ \\
\hline 4 & $\begin{array}{l}\text { Efisiensi waktu dalam proses pengaksesan } \\
\text { informasi dibandingkan dengan sistem yang } \\
\text { lama }\end{array}$ \\
\hline 5 & Kesesuaian aplikasi terupdate \\
\hline 6 & $\begin{array}{l}\text { Ketepatan penggunaan aplikasi sesuai dengan } \\
\text { manfaat }\end{array}$ \\
\hline 7 & $\begin{array}{l}\text { Kesesuaian aplikasi berdasarkan hak akses } \\
\text { user }\end{array}$ \\
\hline 8 & $\begin{array}{l}\text { Penggunaan warna dan rancangan latar } \\
\text { belakang (background) }\end{array}$ \\
\hline 9 & $\begin{array}{l}\text { Penggunaan warna tulisan dengan latar } \\
\text { belakang (background) }\end{array}$ \\
\hline 10 & Penggunaan format ukuran tombol \\
\hline 11 & Penggunaan format warna tombol \\
\hline 12 & $\begin{array}{l}\text { Fungsi tombol dan menu dengan tujuan yang } \\
\text { diinginkan sudah sesuai }\end{array}$ \\
\hline 13 & Ketepatan penamaan tombol dan menu \\
\hline 14 & $\begin{array}{l}\text { Ketepatan pesan yang tampil (berhasil dan } \\
\text { gagal) }\end{array}$ \\
\hline
\end{tabular}

Penelitian ini juga melakukan pengujian Beta. Dimana, hasil yang diperoleh dari pengujian beta terhadap 14 pernyataan yang diajukan kepada beberapa responden dapat ditunjukkan pada Tabel 3 .

Tabel 3. Hasil Pengujian Beta Website Polres Kudus

Pernyataan Skor Persentase Keputusan




\begin{tabular}{cccc}
\hline 1 & 70 & $70 \%$ & Sangat Baik \\
2 & 80 & $80 \%$ & Baik \\
3 & 60 & $60 \%$ & Sangat Baik \\
4 & 80 & $80 \%$ & Sangat Baik \\
5 & 70 & $70 \%$ & Baik \\
6 & 70 & $70 \%$ & Baik \\
7 & 70 & $70 \%$ & Baik \\
8 & 70 & $70 \%$ & Baik \\
9 & 70 & $70 \%$ & Baik \\
10 & 70 & $70 \%$ & Baik \\
11 & 70 & $70 \%$ & Baik \\
12 & 80 & $80 \%$ & Sangat Baik \\
13 & 70 & $70 \%$ & Baik \\
14 & 60 & $60 \%$ & Sangat Baik \\
\hline
\end{tabular}

Berdasarkan hasil pengujian beta dapat disimpulkan bahwa responden menilai aplikasi Sistem Informasi Terpadu Kepolisian Resor Kudus (https://polreskudus.com) layak untuk diterapkan karena kemudahan dalam melakukan proses informasi terpadu sehingga dapat meningkatkan efektifitas dan efisiensi dalam melakukan kebutuhan informasi masyarakat.

\section{KESIMPULAN}

Berdasarkan hasil pengujian blackbox serta pengujian beta, maka dapat diambil kesimpulan penelitian yaitu, Sistem Informasi/Website Polres Kudus dibuat sesuai dengan kebutuhan berdasarkan analisis masalah dan perancangan sistem. Implementasi Sistem Informasi Pelayanan Terpadu Resor Kudus dapat meningkatkan proses pelayanan kepada masyarakat dan meningkatkan efektifitas dan efisiensi. Dengan menggunakan satu aplikasi saja dalam melakukan proses informasi dalam rangka upaya peningkatan kualitas pelayanan informasi publik melalui penyebaran informasi dengan menggunakan website resmi Polres Kudus. Webiste ini membantu masyarakat dalam memperoleh informasi cepat tepat dan efisien, karena dapat mengakses aplikasi website secara online

\section{UCAPAN TERIMA KASIH}

Ucapan terima kasih diucapkan kepada Polres Kudus atas kerjasama dan kepercayaannya kepada Tim untuk pembuatan website resmi Polres Kudus. Terima kasih juga diucapkan kepada LPPM dan seluruh tim yang terlibat dalam pembuatan website resmi Polres Kudus. Semoga kerjasama baik ini dapat terus berjalan dan memberikan dampak positif bagi kedua belah pihak dan kepada seluruh masyarakat atas meningkatnya pelayanan publik.
Betayunanda,R., dkk.,2015. Pembuatan Sistem Informasi Evaluasi Pelayanan Publik (SIEVA) Sekolah Dasar Negeri Pada Kementerian Pendayagunaan Aparatur Negara dan Reformasi Birokrasi. Jurnal Teknologi dan Sistem Komputer, Vol.3 No.1. e-issn: 2338-0403.

Ibrahim, W.H., dan Maita, I., 2017. Sistem Informasi Pelayanan Publik Berbasis Web Pada Dinas Pekerjaan Umum Kabupaten Kampar. Jurnal Ilmiah Rekayasa dan Manajemen Sistem Informasi, Vol. 3, No. 2, Agustus 2017, Hal. 1722. e-ISSN 2502-8995 p-ISSN 2460-8181.

Melinda M., dkk., 2017. Rancang Bangun Sistem Informasi Publik Berbasis Web (Studi Kasus : Desa Durian Kecamatan Padang Cermin Kabupaten Pesawaran). Jurnal TEKNO KOMPAK, Vol. 11, No. 1, 2017, 1-4. ISSN 1412-9663 (print).

Soegiarto, dkk., 2018. Sistem Informasi Pelayanan Masyarakat pada Kantor Kelurahan Guntung Paikat Banjarbaru. Prosiding SNRT (Seminar Nasional Riset Terapan) ISSN 2341-5662 (Cetak), ISSN 2341-5670 (Online). Politeknik Negeri Banjarmasin.

Winarna, T.R., dkk., 2018. Pengembangan Sistem Informasi Pelayanan Surat Keterangan Studi Kasus: Pemerintah Desa Legundi Kecamatan Karangjati Kabupaten Ngawi. Jurnal Pengembangan Teknologi Informasi dan Ilmu Komputer. Vol. 2, No. 12, Desember 2018, hlm. 6235-6243.

\section{DAFTAR PUSTAKA}

